\title{
Efficacy of Pre-Emergence and Post-Emergence Herbicides on Weed Control and Yield in Wheat
}

\author{
Ekamdeep Kaur, Rakesh Sharma* and N.D. Singh
}

Department of Agriculture, Khalsa College, Amritsar, Punjab 143002, India

*Corresponding author

\section{A B S T R A C T}

Keywords

Atlantis, Clodinofop,

Pendimethalin,

Pinoxaden, Sulfosulfuron,

Weed control efficiency,

Yield

Article Info

Accepted:

10 January 2018

Available Online:

10 February 2018
The field experiment was conducted at the Student's Research Farm, P.G. Department of Agriculture, Khalsa College, Amritsar, Punjab, to study the efficacy of pre-emergence and post-emergence herbicides on wheat yield during 2016-17. The experiment was laid out in randomized block design with eight treatments such as Weed free, Weedy check, Pendimethalin 2.5L/ha, Pendimethalin $3.75 \mathrm{~L} / \mathrm{ha}$, Clodinofop $400 \mathrm{~g} / \mathrm{ha}$, Sulfosulfuron $32.5 \mathrm{~g} / \mathrm{ha}$, Pinoxaden $1000 \mathrm{ml} / \mathrm{ha}$, Atlantis 400g/ha and replicated thrice. Results revealed that Pendimethalin $(3.75 \mathrm{~L} / \mathrm{ha})$ was found effective to control weed population and produced higher number of effective tillers, 1000 grain weight and enhanced the yield upto $43.1 \%$ over weedy check.

\section{Introduction}

Wheat (Triticum aestivum) is the most important winter cereal crop of Punjab and staple food for millions of people in India and across the world. Regardless of all the other ways of crop yield enhancement, weed control is one of the important key factors in crop yield improvement particularly in Amritsar districts to cope with the annual weed population blast. Weeds compete with crop for available moisture, nutrients, space, light and provide shelter for harmful insect-pests which result in yield reduction. Weeds cause yield reduction upto 15-50 percent depending upon the weed density and weed flora (Jat et al., 2003). Weeds not only reduce yield but also lower the quality of the produce and increases the cost of harvesting, threshing and cleaning.

Apart from improved agronomic practices and preventive measures, chemical weed control is one of the important key factors to enhance the wheat production and productivity. Most of the small, medium and large farmers of Amritsar district are well aware about integrated weed control strategies, even though chemical weed control measures have prominent place and popularity among them. Therefore, proper selection of herbicide and time of application remains the only resort to check weed population and to improve crop yield. Herbicidal treatments increased grain yield as compared with un-weeded and hand 
weeding treatments (Amin et al., 2008). But as a part of rat-race among each other the farmers use excessive chemicals which are not only pollute the environment but hazardous human health too. That's why choice of best herbicide and time of application are the important consideration for lucrative returns. Keeping in view the importance of weeds problem in wheat, this study was undertaken to investigate the effectiveness of different herbicides for controlling the weeds in wheat crop.

\section{Materials and Methods}

The experiment was conducted at Students' Research Farm, Khalsa College, Amritsar during rabi season of 2016-17. Amritsar is located at $31^{\circ}-38^{\circ}$ North latitude and $74^{\circ}$ $52^{\circ}$ East longitude and at an altitude of 236 meters above mean sea level. Maximum temperature ranged between $14.9^{\circ} \mathrm{C}$ and $41.2^{\circ}$ $\mathrm{C}$ while minimum temperature ranged between $1.9{ }^{\circ} \mathrm{C}$ and $23.3^{\circ} \mathrm{C}$ during this season. The soil of experimental site was sandy loam having $\mathrm{pH} 7.8$, medium in organic carbon $(0.49 \%)$, low available N (164.5 kg/ha), high available $\mathrm{P}(31.7 \mathrm{~kg} / \mathrm{ha})$ and high available $\mathrm{K}$ (347.5 kg/ha). The wheat variety ' $W H 1105$ ' was sown at $22.5 \mathrm{~cm}$ spacing on $5^{\text {th }}$ November 2016. The experiment was laid out in randomized block design with eight treatments such as Weed free, Weedy check, Pendimethalin 2.5L/ ha, Pendimethalin 3.75L/ha, Clodinofop 400g/ha, Sulfosulfuron 32.5g/ha, Pinoxaden $1000 \mathrm{ml} / \mathrm{ha}$, Atlantis $400 \mathrm{~g} / \mathrm{ha}$ and replicated thrice. The gross plot size was $4.5 \mathrm{~m} \times 4.5 \mathrm{~m}$. Herbicides were applied with knapsack sprayer. Pendimethalin was applied as pre-emergence at two day after sowing, while clodinofop, sulfosulfuron, pinoxaden and atlantis were applied as postemergence at 32 DAS. The weed density and dry weight of weeds- grass and broad-leaf weeds were analyzed using transformation of square root i.e., $(\sqrt{x+1})$, before carrying out analysis of variance and comparison were made on transformed values.

The weed control efficiency was calculated by using the following formula:

$\operatorname{WCE}(\%)=\frac{\text { DMC-DMT }}{\mathrm{DMC}} \times 100$

(Where, WCE $=$ Weed control efficiency in percent, DMC = Dry matter weight of weeds in control plot and DMT = Dry matter weight of weeds in treated plots)

\section{Results and Discussion}

The data recorded on weed density (number $/ \mathrm{m}^{2}$ ), weed dry matter $\left(\mathrm{g} / \mathrm{m}^{2}\right)$, weed control efficiency (\%),effective tillers (number $/ \mathrm{m}^{2}$ ), test weight $(\mathrm{g})$, straw yield $(\mathrm{t} / \mathrm{ha})$ and grain yield (t/ha) were significantly affected by different herbicides treatments.

\section{Effect on weeds}

The density and dry matter of narrow and broad weeds decreased significantly as compared to weedy check. The decline in weed density and weed dry matter was owed to withering of weeds (Table 1 and 2). Removing the weeds whenever they appear under the weed free treatment resulted in complete elimination of weed competition as it resulted in lowest total weed dry weight. Among pre-emergence herbicide treated plots, the maximum reduction of narrow weeds and broad weeds were observed with the application of pendimethalin @ 3.75 L/ ha followed by pendimethalin @ $2.5 \mathrm{~L} / \mathrm{ha}$. The higher dose of pendimethalin was more effective in controlling weeds than the lower dose (Kaur et al., 2010). Among post emergence treated plots, atlantis @ $400 \mathrm{~g}$ provide effective control on weed population and lowest weed dry matter being par with pendimethalin. 
Table.1 Effect of different weed control treatments on population (number $/ \mathrm{m}^{2}$ ) of narrow weeds and dry matter of narrow weeds $\left(\mathrm{g} / \mathrm{m}^{2}\right)$ in wheat (Triticum aestivum)

\begin{tabular}{|c|c|c|c|c|c|c|}
\hline \multirow[t]{2}{*}{ Treatments } & \multicolumn{4}{|c|}{ Narrow weeds/ $\mathbf{m}^{2}$} & \multicolumn{2}{|c|}{$\begin{array}{l}\text { Dry matter of narrow } \\
\text { weeds }\left(\mathrm{g} / \mathrm{m}^{2}\right)\end{array}$} \\
\hline & $\begin{array}{l}30 \\
\text { DAS }\end{array}$ & $\begin{array}{l}60 \\
\text { DAS }\end{array}$ & $\begin{array}{l}\text { At } \\
\text { harvest }\end{array}$ & $\begin{array}{l}30 \\
\text { DAS }\end{array}$ & $\begin{array}{l}60 \\
\text { DAS }\end{array}$ & $\begin{array}{l}\text { At } \\
\text { harvest }\end{array}$ \\
\hline Weed free & $1(0)$ & $1(0)$ & $1(0)$ & $1(0)$ & $1(0)$ & $1(0)$ \\
\hline Weedy check & $9.0(80.6)$ & $8.1(64.2)$ & $7.6(58.2)$ & $3.2(9.8)$ & $6.4(40.5)$ & $14.8(221)$ \\
\hline $\begin{array}{l}\text { Pendimethalin } \\
(2.5 \mathrm{~L} / \mathrm{ha})\end{array}$ & $2.7(6.34)$ & $2.6(5.63)$ & $2.3(4.44)$ & $1.3(0.7)$ & $2.9(7.8)$ & $6.7(44.5)$ \\
\hline $\begin{array}{l}\text { Pendimethalin }(3.75 \\
\text { L/ha) }\end{array}$ & $2.7(6.29)$ & $2.5(5.34)$ & $2.0(3.03)$ & $1.1(0.4)$ & $2.5(5.6)$ & $6.2(37.5)$ \\
\hline $\begin{array}{l}\text { Clodinofop }(400 \\
\text { g/ha) }\end{array}$ & $8.9(79.2)$ & $3.1(8.86)$ & $2.7(6.46)$ & $3.3(9.7)$ & $3.7(13.2)$ & $6.0(35.4)$ \\
\hline $\begin{array}{l}\text { Sulfosulfluron }(32.5 \\
\text { g/ha) }\end{array}$ & $8.8(76.6)$ & $3.9(14.9)$ & $3.6(12.5)$ & $3.2(9.4)$ & $4.8(22.7)$ & $7.9(62.3)$ \\
\hline $\begin{array}{l}\text { Pinoxaden }(1000 \\
\mathrm{ml} / \mathrm{ha})\end{array}$ & $8.8(76.8)$ & $3.5(11.9)$ & $2.9(7.95)$ & $3.2(9.4)$ & $4.5(19.8)$ & $7.0(48.6)$ \\
\hline Atlantis(400 g/ha) & $8.7(76.4)$ & $2.3(4.31)$ & $2.0(3.02)$ & $3.2(9.3)$ & $3.4(10.3)$ & $5.6(33.1)$ \\
\hline $\operatorname{LSD}(p=0.05)$ & 1.69 & 0.49 & 0.34 & 1.4 & 1.5 & 1.8 \\
\hline
\end{tabular}

Original data given in parenthesis was subjected to square root $(+1)$ transformation before analysis

Table.2 Effect of different weed control treatments on population (number/ $\mathrm{m}^{2}$ ) of broad weeds and dry matter of broad weeds $\left(\mathrm{g} / \mathrm{m}^{2}\right)$ in wheat (Triticum aestivum)

\begin{tabular}{|c|c|c|c|c|c|c|}
\hline \multirow[t]{2}{*}{ Treatments } & \multicolumn{3}{|c|}{ Broad weeds/ $\mathbf{m}^{2}$} & \multicolumn{3}{|c|}{$\begin{array}{c}\text { Dry weight of broad Weeds } \\
\qquad\left(\mathrm{g} / \mathrm{m}^{2}\right)\end{array}$} \\
\hline & $\begin{array}{l}\text { 30 } \\
\text { DAS }\end{array}$ & $\begin{array}{l}\text { 60 } \\
\text { DAS }\end{array}$ & $\begin{array}{l}\text { At } \\
\text { harvest }\end{array}$ & $\begin{array}{l}\text { 30 } \\
\text { DAS }\end{array}$ & $\begin{array}{l}\text { 60 } \\
\text { DAS }\end{array}$ & At harvest \\
\hline Weed free & $1(0)$ & $1(0)$ & $1(0)$ & $1(0)$ & $1(0)$ & $1(0)$ \\
\hline Weedy check & $8.7(79.7)$ & $8.7(75.6)$ & $8.3(68.4)$ & 4.4(18.4) & $7.8(60.3)$ & $16.5(273.1)$ \\
\hline $\begin{array}{l}\text { Pendimethalin } \\
(2.5 \mathrm{~L} / \mathrm{ha})\end{array}$ & $2.9(7.84)$ & $2.9(7.98)$ & 2.7(6.54) & 1.4(1.1) & $3.0(9.3)$ & $9.5(91.0)$ \\
\hline $\begin{array}{l}\text { Pendimethalin } \\
(3.75 \mathrm{~L} / \mathrm{ha})\end{array}$ & 2 & $2.6(5.64)$ & 2. & $1.2(0.6)$ & $2.4(8.4)$ & $8.8(77.1)$ \\
\hline $\begin{array}{l}\text { Clodinofop } \\
\text { g/ha) }\end{array}$ & $8.8(76.8)$ & $5.1(25.0)$ & $5.3(27.2)$ & $4.2(17.2)$ & $7.2(50.5)$ & $11.6(135.1)$ \\
\hline $\begin{array}{l}\text { Sulfosulfluron } \\
(32.5 \mathrm{~g} / \mathrm{ha})\end{array}$ & $8.7(75.2)$ & $2.5(4.31)$ & $2.5(5.73)$ & $4.1(16.4)$ & $4.7(21.1)$ & $9.9(98.7)$ \\
\hline $\begin{array}{l}\text { Pinoxaden } \\
\mathrm{ml} / \mathrm{ha})\end{array}$ & $8.7(75.8)$ & $5.1(25.8)$ & $5.4(27.5)$ & 4.2(16.6) & $6.9(47.8)$ & $11.9(142.2)$ \\
\hline Atlantis $(400 \mathrm{~g} / \mathrm{ha})$ & $8.8(77.2)$ & $2.5(5.26)$ & $2.5(5.11)$ & $4.3(17.5)$ & $4.6(20.8)$ & $10.1(101.1)$ \\
\hline $\operatorname{LSD}(p=0.05)$ & 1.63 & 0.46 & 0.44 & 2.3 & 1.9 & 1.3 \\
\hline
\end{tabular}

Original data given in parenthesis was subjected to square root $(+1)$ transformation before analysis 
Table.3 Effect of different weed control treatments on weed control efficiency (\%) in wheat (Triticum aestivum)

\begin{tabular}{|l|l|}
\hline Treatments & Weed control Efficiency $(\%)$ \\
\hline Weed free & 100 \\
\hline Weedy check & - \\
\hline Pendimethalin $(\mathbf{2 . 5} / \mathbf{h a})$ & 72.6 \\
\hline Pendimethalin $(\mathbf{3 . 7 5} \mathbf{~ L / h a )}$ & 76.9 \\
\hline Clodinofop $(\mathbf{4 0 0} \mathbf{g} / \mathbf{h a})$ & 65.6 \\
\hline Sulfosulfluron $(\mathbf{3 2 . 5} \mathbf{g} / \mathbf{h a})$ & 67.4 \\
\hline Pinoxaden $(\mathbf{1 0 0 0} \mathbf{~ m l} / \mathbf{h a})$ & 61.3 \\
\hline Atlantis $(\mathbf{4 0 0} \mathbf{g} / \mathbf{h a})$ & 72.8 \\
\hline
\end{tabular}

Table.4 Effect of different weed control treatments on effective tillers (number/ $\mathrm{m}^{2}$ ) and test weight (g), grain yield ( $\mathrm{t} / \mathrm{ha}$ ) and straw yield (t/ha) of wheat (Triticum aestivum)

\begin{tabular}{|c|c|c|c|c|}
\hline Treatments & $\begin{array}{l}\text { Effective } \\
\text { tillers } / \mathbf{m}^{2}\end{array}$ & $\begin{array}{c}\text { Test weight } \\
\text { (g) }\end{array}$ & $\begin{array}{c}\text { Grain } \\
\text { Yield (t /ha) }\end{array}$ & $\begin{array}{c}\text { Straw } \\
\text { Yield (t/ ha) }\end{array}$ \\
\hline Weed free & 406.4 & 38.7 & 5.88 & 9.19 \\
\hline Weedy check & 347.2 & 34.4 & 3.63 & 6.77 \\
\hline Pendimethalin (2.5L/ha) & 384.0 & 37.7 & 5.10 & 8.24 \\
\hline Pendimethalin(3.75 L/ha) & 384.4 & 37.9 & 5.19 & 8.29 \\
\hline Clodinofop (400 g/ha) & 365.9 & 36.9 & 4.40 & 7.50 \\
\hline Sulfosulfluron $(32.5 \mathrm{~g} / \mathrm{ha})$ & 383.7 & 37.0 & 4.86 & 8.14 \\
\hline Pinoxaden(1000 ml/ha) & 364.8 & 36.8 & 4.38 & 7.49 \\
\hline Atlantis(400 g/ha) & 383.7 & 37.4 & 5.07 & 8.23 \\
\hline $\operatorname{LSD}(p=0.05)$ & 16.02 & 2.80 & 0.35 & 0.42 \\
\hline
\end{tabular}

The highest weed population and dry matter was observed in weedy check. The results are in line with those of Walia et al., (2012).

The weed control efficiency among the weed control management practices ranged from 61.3 to $100 \%$. The highest weed control efficiency was found in weed free plots followed by pendimethalin @ $3.75 \mathrm{~L} / \mathrm{ha}$ (76.9\%). The lowest weed control efficiency (61.3\%) was recorded in where pinoxaden @ $1000 \mathrm{ml} /$ ha was used (Table 3).

\section{Effect on crop}

Grain and straw yield differed significantly due to different weed control treatments
(Table 4). Weed control treatments registered significantly higher grain and straw yield than weedy check. The higher grain and straw yield was recorded with application of pendimethalin @ 3.75 L/ha (5.19 and 8.29 t/ha respectively) which was at par with pendimethalin@2.5 L/ha (5.10 and 8.24 t/ha respectively), atlantis@ @ $400 \mathrm{~g} / \mathrm{ha}$ (5.07 and $8.23 \mathrm{t} / \mathrm{ha}$ ) and sulfosulfuron @ $32.5 \mathrm{~g} / \mathrm{ha}$ (4.86 and 8.14 t/ha respectively). The higher grain and straw yield in these treatments is mainly due to better control of weeds and higher weed control efficiency during early stage of crop growth which resulted in effective utilization of resources such as nutrients, moisture, space and light resulted in better expression yield component viz., 
number of effective tillers per $\mathrm{m}^{2}$ (384.4, $384.0,383.7$ and 383.7 respectively) and the test weight $\mathrm{g}(37.9,37.7,37.4$ and 37.0 respectively). Whereas, lower grain and straw yield was recorded with weedy check (3.63 and $6.77 \mathrm{t} / \mathrm{ha}$ respectively) owing to severe crop weed competition which resulted in reduction in the expression of yield components such as effective tillers per $\mathrm{m}^{2}$ (347.2). It was further observed that the lowest test weight (36.8 g) was obtained from pinoxaden followed by clodinofop (36.9 g) treated plots, which was statistically equal $(34.4 \mathrm{~g})$ to the weedy check plots which in turn was statistically lower with the remaining herbicidal treatments. These results are in conformity with the findings of Khalil et al., (2013), Hussain et al., (2013), Chemma et al., (2006) and Ali et al., (2004).

It can be concluded that, application of pendimethalin $3.75 \mathrm{~L} / \mathrm{ha}$ as pre emergence is the best weed management practice in wheat to obtain greater yield with more efficient weed control.

\section{References}

Ali, M., Sabir, S., Mohy-ud-Din, Q. and Ali, M.A. (2004) Efficacy and economics of different herbicides against narrow leaved weeds in wheat. International Journal of Agriculture Biology 6(4): 647-651.

Amin, A., Khan, M.A., Hassan, G., Marwat, K.B., Rashid, H. and Nawab, K. (2008) Weed control efficacy and economics of pre-emergence herbicides in maize (Zea mays). The Asian Autralian Journal of Plant Science Biotechnology 2(2): 7275.

Cheema, M.S., Akhtar, S. and Iqbal, M.S. (2006) Performance of different herbicides in wheat under irrigated conditions of southern Punjab, Pakistan. Pakistan Journal of Weed Science Research 12(1-2): 53-59.

Hussain, Z., Marwat, K.H., Munsif, F., Samad, A. and Ali, K. (2013) Evaluation of various herbicides and their combinations for weed control in wheat crop. Pakistan Journal of Botany 45(1): 55-59.

Jat, R.S., Nepalia, V. and Chaudhary, P.D. (2003) Influence of herbicide and methods of sowing on weed dynamics in wheat (Triticum aestivum). Indian Journal of Weed Science 35: 18-20.

Kaur, G., Brar, H.S. and Singh, G. (2010) Effect of weed management on weeds, nutrient uptake, nodulation, growth and yield of summer mungbean (Vigna radiata) Indian Journal of Weed Science 42(1\&2): 114-119.

Khalil, M.F., Hussan, G., Ahmad, G., Anwar, S. and Khan, S. (2013) Comparative efficacy of herbicides on yield and yield components of wheat (Triticum aestivum). APRN Journal of Agriculture Biological Science 8(1): 76-80.

Walia, U.S., Walia, S.S., Sidhu, A.S. and Nayyar, S. (2012) Bioefficacy of preand post- emergence herbicides in direct-seeded rice in Central Punjab. Indian Journal of Weed Science 44(1): 30-33.

\section{How to cite this article:}

Ekamdeep Kaur, Rakesh Sharma and Singh, N.D. 2018. Efficacy of Pre-Emergence and PostEmergence Herbicides on Weed Control and Yield in Wheat. Int.J.Curr.Microbiol.App.Sci. 7(02): 883-887. doi: https://doi.org/10.20546/ijcmas.2018.702.111 